\title{
GAMBARAN DIMENSI KEPUASAN PELANGGAN PERUSAHAAN JASA EKSPEDISI SICEPAT
}

\author{
Intan Fazria Kusumah \\ Universitas Pendidikan Indonesia \\ intanfazria@student.co.upi.edu \\ Lili Adi Wibowo \\ Universitas Pendidikan Indonesia \\ liliadiwibowo@upi.edu \\ Ridwan Purnama \\ Universitas Pendidikan Indonesia \\ ridwanpurnama@upi.edu
}

\begin{abstract}
ABSTRAK
Tujuan -Tujuan dari penelitian ini adalah untuk mengetahui gambaran pelaksanaan dimensi kepuasan pelanggan perusahaan jasa ekspedisi sicepat.

Desain / metodologi / pendekatan - Penelitian ini dilakukan pada jangka waktu kurang dari 1 tahun, maka desain penelitian adalah desain cross-sectional.Dan metode yang digunakan adalah survei explanatory, dan populasi 203 karyawan. Teknik analisis yang digunakan adalah deskriptif, kuesioner digunakan sebagai instrumen penelitian untuk mengumpulkan data dari responden.

Temuan - berdasarkan hasil penelitian menggunakan analisis regresi linear sederhana, didapatkan hasil bahwa terdapat pengaruh positif antara Service Innovation berpengaruh terhadap kepuasan pelanggan.

Orisinilitas/nilai - penelitian ini memberikan dasar untuk memahami dampak dari Service Innovation terhadap Kepuasan pelanggan.
\end{abstract}

Kata kunci: Service Innovation, customer satisfaction, expectation satisfaction, overall satisfaction,experience satisfaction.

Jenis Artikel: Penelitian

\section{ABSTRACT}

Purpose - The purpose of this study is to determine the effect of Service Innovation on Customer Satisfaction

Design / methodology / approach - This research was conducted in less than 1 year period, the research design is cross-sectional design. The method used is explanatory survey, and population 203 employees. The analysis technique used is descriptive, the questionnaire is used as a research instrument to collect data from respondents.

Findings - based on the results of the study using simple linear regression analysis, the result that there is a positive influence of service innovation on customer satisfaction.

Originality / value - this study provides a basis for find out the impact of service innovation on customer satisfaction.. The difference of this study with previous research is on the objects, variables, theories and the references.

Keywords:Service Innovation, customer satisfaction, expectation satisfaction, overall satisfaction,experience satisfaction.

Article Type: Research Paper 


\section{PENDAHULUAN}

Salah satu kegiatan pokok yang dilakukan perusahaan untuk mempertahankan perusahaannya dalam memenuhi kebutuhan dan keinginan konsumennya adalah dengan melakukan kegiatan pemasaran. (Kotler dan Keller (2016:27) Memahami pasar terutama kebutuhan dan keinginan konsumen adalah keberhasilan pemasaran. Dalam arti luas pasar mengacu pada dunia perdagangan, sedangkan dalam arti sempit pasar dapat dibagi atau dibagi ke dalam kelompok orang-orang yang berhubungan dengan organisasi karena alasan tertentu.Hal ini sesuai dengan pendapat yang dikemukakan oleh (Grewal dan Levy; 2013:5) "Marketing is about satisfying customer needs and wants".

Salah satu unsur dari total nilai konsumen adalah kepuasan pelanggan dimana kualitas pelayanan merupakan unsur utama yang bersifat positif dalam pembentukan nilai konsumen. Kualitas pelayanan bagi konsumen sendiri merupakan pembentuk dari kepuasan konsumen (Fandy Tjiptono (2011:24)). Hal tersebut sesuai dengan konsep kepuasan konsumen pada Gambar 1.1 berikut ini:

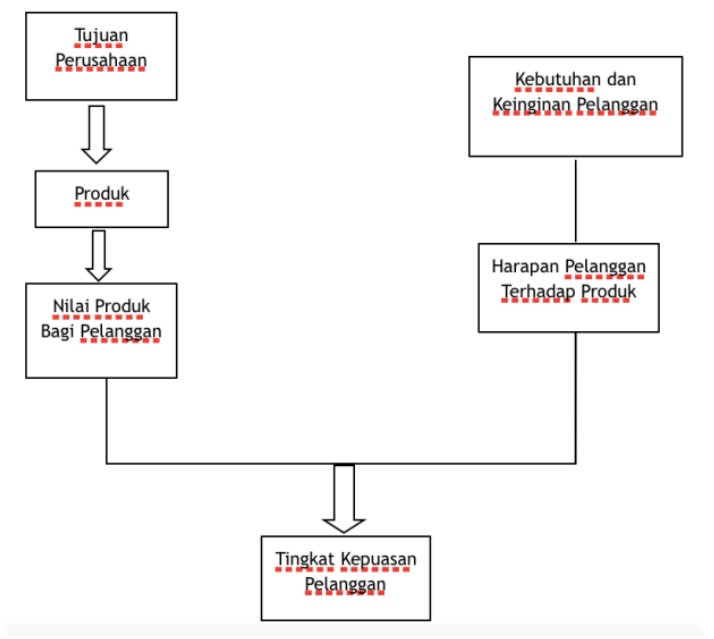

GAMBAR 1.1
KONSEP KEPUASAN KONSUMEN

Seiring berkembangnya teknologi konsumen tidak lagi membutuhkan service yang biasa saja, perusahaan harus mempunyai pembeda dalam segi pelayanan agar harapan pelanggan sesuai dengan service yang diberikan dan pelanggan merasa puas. Jasa ekspedisi yang mengalami peningkatan dari tahun ke tahun di Indonesia menunjukkan bahwa banyaknya pelanggan yang merasa puas menggunakan jasa tersebut. Seiring dengan perkembangan jasa ekspedisi yang terus meningkat Asosiasi Perusahaan Jasa Pengiriman Express, Pos dan Logistik (Asperindo) menyatakan pada tahun 2016 potensi industri jasa ekspedisi masih akan terus meningkat. Hal ini disebabkan karena semakin berkembangnya pertumbuhan bisnis online di Indonesia (www.bisniskurir.com).

Kualitas pelayanan dan inovasi pada perusahaan jasa ekpedisi semakin ditingkatkan agar terciptanya kepuasan pelanggan. Kepuasaan pelanggan dalam produk dan jasa yang diberikan dapat menjadi kesuksesan suatu perusahaan (Thurau dan klee,1977). Salah satu faktor penting dalam jasa ekspedisi adalah kepuasaan pelanggan ((Mosahab, Mahamad,Ramayah, 2010). Semua perusahaan jasa termasuk jasa ekspedisi harus mengutamakan pelayanan dan kepuasan agar dapat tetap mempertahankan pelanggan ((Dehdahshti dan Bahrai Nizade et all 2013:115). Tantangan terbesar untuk penyedia jasa tergantung pada kualitas jasa yang diberikan dan kepuasan pelanggan yang tinggi. Kepuasan pelanggan merupakan penilaian pribadi setelah menggunakan suatu produk atau jasa yang sangat dipengaruhi oleh harapan pelanggan itu sendiri. Kepuasan pelanggan mengacu pada evaluasi secara keseluruhan dari pelanggan terhadap kinerja suatu layanan (Hung dan Chen, Cengiz Umrah, Gustaffson et al dalam Mahmoudi Maymand, 2015:142).

Pelanggan akan mengevaluasi produk dan jasa yang telah dibeli dan digunakan karena konsumen harus mengulangi tahapan pembelian untuk mengetahui apakah produk dan jasa yang telah dibelisudah memenuhi kebutuhan dan harapan atau tidak, apabila tidak apakah ada alternatif lain sebagai pengganti produk dan jasa tersebut yang lebih baik lagi. (Lili Adi Wibowo dan Yeni Yuniawati, 2007)

Meningkatnya permintaan di bisnis online berpegaruh pada jasa pengiriman barang atau jasa ekspedisi. Perusahaan jasa ekspedisi yang telah dikenal masyarakat adalah JNE, TIKI, Pos Indonesia, DHL dan Sicepat Ekspress. Jumlah pengiriman perusaahan ini terus meningkat seperti pada Tabel 1.1 berikut ini: 
TABEL 1.1

JUMLAH PENGIRIMAN PERUSAHAAN JASA EKSPEDISI DI INDONESIA

\begin{tabular}{lcc}
\hline Nama Jasa Ekspedisi & $\mathbf{2 0 1 4}$ & $\mathbf{2 0 1 5}$ \\
\hline JNE & 6000.000 & 12.000 .000 \\
TIKI & 5560.000 & 9450.000 \\
Pos Indonesia & 2200.000 & 2900.000 \\
DHL & 889.000 & 912.000 \\
Sicepat ekspress & 645.000 & 892.000 \\
\hline
\end{tabular}

Sumber: Data dari berbagai sumber

Berdasarkan Tabel 1.1 terlihat bahwa jumlah pengiriman perusahaan ekspedisi semakin meningkat di tahun 2015. Namun perusahaan yang terkecil jumlah pengirimannya di tahun 2015 adalah Sicepat ekspress. Sicepat merupakan perusahaan yang fokus melayani online shop sejak tahun 2004.

Kurang berkembangnya jasa ekspedisi sicepat ekspress dapat dipengaruhi oleh beberapa faktor sehingga turunnya tingkat kepuasan pelanggan. Apabila suatu perusahaan tidak memperhatikan aspek pemasaran, khususnya tingkat kepuasan pelanggannya maka perusahaan tersebut tidak akan dapat berjalan dengan baik (Wibowo dan Novita 2015:2).

Turunnya kepuasan pelanggan mampu memberikan dampak negatif pada perusahaan, karena kepuasan suatu produk dan jasa dapat memberikan gambaran pada pengguna terhadap produk dan jasa tersebut untuk terus menggunakan atau beralih ke produk dan jasa yang lainya yang sejenis. Tujuan dari penelitian ini adalah untuk mendapatkan hasil penelitian mengenai gambaran kepuasan pelanggan pada komunitas online shop di Indonesia.

\section{KAJIAN PUSTAKA}

Salah satu kegiatan pokok yang dilakukan perusahaan untuk mempertahankan perusahaannya dalam memenuhi kebutuhan dan keinginan konsumennya adalah dengan melakukan kegiatan pemasaran. Kotler dan Keller (2016:27) "Marketing is about identifying and meeting human and social needs. One of the shortest good definitions of marketing is "meeting needs profitably". Pemasaran merupakan landasan utama dalam bisnis dan masyarakat. Kemampuan untuk mengenali kebutuhan dan keinginan konsumen dan mengombinasikannya dengan kondisi pasar merupakan kegiatan utama bagi suatu perusahaan untuk daat memertahankan kelangsungan hidup perusahaan agar tetap eksis karena pemasaran adalah ujung tombak dalam proses penjualan.
Memahami pasar terutama kebutuhan dan keinginan konsumen adalah keberhasilan pemasaran. Dalam arti luas pasar mengacu pada dunia perdagangan, sedangkan dalam arti sempit pasar dapat dibagi atau dibagi ke dalam kelompok orang-orang yang berhubungan dengan organisasi karena alasan tertentu. Hal ini sesuai dengan pendapat yang dikemukakan oleh Grewal dan Levy (2013:5) "Marketing is about satisfying customer needs and wants"

Sejalan dengan pengertian tersebut maka dibutuhkan komunikasi dan strategi yang merupakan bagian penting dalam proses pemasaran sehingga nilai dari suatu produk dan jasa sampai kepada para konsumen. Dalam pemasaran perlu dilakukannya service quality yang akan meningkatkan kepuasaan suatu pelanggan.

Pada prinsipnya, definisi kualitas jasa berfokus pada upaya pemenuhan kebutuhan dan keinginan konsumen serta ketepatan penyampaiannya untuk mengimbangi harapan konsumen. Dalam service quality terdapat salah satu indikatornya dengan menciptakan service innovation untuk menarik pelanggan.

Setiap aktivitas perusahaan yang ada harus difokuskan pada upaya untuk memberikan kinerja pelayanan melebihi harapan konsumen (Lili Adi Wibowo dan Gitashiswara, 2014). Agar dapat bertahan dan/atau berkembang, perusahaan perlu melakukan kreatifitas dan inovasi atas atribut produknya, serta memelihara keunikannya secara berkelanjutan. (Agus Rahayu, 2010). Semakin berkembangnya suatu industry maka semakin banyak juga pesaing didalamnya. Strategi bisnis dan keunggulan bersaing sangat penting untuk dijadikan pedoman dalam pengembangan strategi pemasaran (Ratih Hurriyati, 2010)

Perusahaan harus selalu berinovasi dalam memberikan pelayanan yang prima, agar terciptanya kepuasan pelanggan.

Kepuasan pelanggan didefinisikan sebagai respon pelanggan terhadap ketidaksesuain antara tingkat kepentingan sebelumnya dan kinerja aktual yang dirasakannya setelah pemakaian (Freddy Rangkuti, 2009)

Faktor-faktor yang berpengaruh terhadap kepuasan pelanggan yaitu service innovation, servicescape, service delivery, service delight, serviced design, service performance, service purchase, service process). (Zeithaml, Bitner, Gremler, 2009) .

Inovasi dalam pelayanan merupakan hal yang penting agar pelanggan dapat terus loyal menggunakan produk dan jasa yang kita berikan. Inovasi layanan dapat dilakukan dari internal atau eksternal perusahaan. Inovasi layanan secara internal perusahaan dapat memberikan kenyamanan dan semangat baru untuk pegawai 
agar giat bekerja, sedangkan inovasi layanan secara eksternal dapat membangun daya tarik pelanggan untuk memakai jasa yang ada pada perusahaan.

Hasil penelitian dalam jasa ekspedisi di Malaysia menunjukkan bahwa semua aspek kualitas pelayanan berpengaruh terhadap kepuasan pelanggan (Delafrooz, Taleghani, Taghineghad dan Nademi,2013).

\section{METODE PENELITIAN}

Penelitian ini menggunakan pendekatan manajemen pemasaran khususnya mengenai kepuasan pelanggan. Adapun yang menjadi objek penelitian kepuasan pelanggan unsurnya terdiri dari Expectation Satisfaction, Overall Satisfaction, Experience Satisfaction. Objek yang dijadikan responden dalam penelitian ini adalah komunitas online shop di Indonesia.

Penelitian ini dilakukan dalam kurun waktu tertentu, maka metode yang digunakan adalah Cross Sectional Method. Metode yang dilakukan pada satu waktu tertentu saja tidak berkesinambungan dalam waktu panjang.

Metode penelitian yang dipakai dalam penelitian ini adalah deskriptif. David A. Aaker 2004:755) menjelaskan bahwa riset deskriptif adalah "Research that usually is designed to provide a summary ofsome aspect of the environment when the hypotheses are tentative and speculative in nature”. Artinya riset yang biasanya didesain untuk menyajikan beberapa aspek yang bersifat tentatif dan spekulatif dalam suatu cakupan/bahasan. (Naresh K.Malhotra 2009:100) menjelaskan bahwa, penelitian deskriptif adalah jenis penelitian konklusif yang memiliki tujuan utama deskripsi dari sesuatu, biasanya karakteristik atau fungsi pasar. Melalui jenis penelitian deskriptif maka dapat diperoleh gambaran mengenai kepuasan pelanggan pada pengguna jasa ekspedisi sicepat ekspress.

Operasionalisasi variabel merupakan kegiatan implementasi dari variabel ke dalam konsep teori dari variabel yang diteliti, indikator, ukuran dan skala yang bertujuan untuk mendefinisikan dan mengukur variabel. Variabelvariabel yang akan diteliti adalah variabel ekuitas merek berbasis pelanggan yaitu: Expectation Satisfaction, Overall Satisfaction, Experience Satisfaction.

Sumber data dalam penelitian adalah subyek dari mana data dapat diperoleh. Berdasarkan sumbernya, data dibedakan menjadi dua yaitu data primer dan data sekunder. Data primer adalah sumber yang langsung memberikan data kepada pengumpul data, dan data sekunder merupakan sumber yang tidak langsung memberikan data kepada pengumpul data (Sugiyono, 2017). Dalam penelitian ini sumber data yang dipakai adalah Data Primer, pada penelitian ini yang menjadi sumber data primer adalah instrumen yang disebarkan kepada sejumlah responden, sesuai dengan target sasaran dan dianggap mewakili seluruh populasi data penelitian, yakni survei pada komunitas fanpage facebook Oriflame. Data Sekunder, pada penelitian ini yang menjadi sumber data sekunder adalah literatur, jurnal, artikel serta situs internet yang berkenaan dengan penelitian.

Populasi dalam penelitian ini adalah 203 anggota. Agar memperoleh sampel yang representatif dari populasi maka setiap subjek dalam populasi diupayakan untuk memiliki peluang yang sama untuk menjadi sampel. Adapun rumus yang digunakan untuk mengambil suatu sampel dari sebuah populasi ialah dengan menggunakan rumus (Harun Al Rasyid, 1994). Dalam penelitian ini ukuran sampel minimal adalah 203 responden. Pengumpulan data yang dilakukan penulis menggunakan teknik sebagai berikut: Studi kepustakaan, yaitu suatu pengumpulan data dengan cara mempelajari buku, makalah, website dan majalah untuk memperoleh informasi yang berhubungan dengan teori dan konsep yang berkaitan dengan masalah dan variabel yang diteliti yang terdiri dari Service Innovation dan Kepuasaan Pelanggan. Kuisioner dilakukan dengan menyebarkan seperangkat daftar pertanyaan kepada responden. Dalam kuisioner ini penulis mengemukakan beberapa pertanyaan yang mencerminkan pengukuran indikator variable kepuasan pembelian. Kemudian memilih alternatif jawaban yang telah disediakan pada masing-masing alternatif jawaban yang tepat. Kuisioner yang disebar oleh peneliti di sebar secara umum kepada responden.

Langkah-langkah penyusunan kuisioner adalah sebagai berikut : a) Menyusun kisi-kisi angket atau daftar pertanyaan, (b) Merumuskan item pertanyaan dan alternatif jawaban. Jenis instrumen yang digunakan dalam angket merupakan instrumen yang bersifat tertutup, yaitu seperangkat alat tluis dan disertai dengan alternatif jawaban yang disediakan, sehingga responden hanya memilih jawaban tersedia. (c) Menetapkan pemberian skor untuk item pertanyaan. Pada penelitian ini setiap pendapat responden atas pertanyaan diberi nilai dengan skala interval. (d)Studi literatur merupakan usaha pengumpulan informasi yang berhubungan dengan teori yang ada kaitannya dengan masalah dan variabel yang diteliti yang terdiri dari Service Innovation dan Kepuasan Pelanggan. Studi literatur tersebut didapat dari berbagai sumber 
yaitu : a) Perpustakaan Universitas; b)Skripsi; c)Jurnal penelitian Ekonomi dan Bisnis; d)Media Cetak (majalah) dan e)Media Elektronik (Internet).

Penelitian ini menggunakan teknik analisis data deskriptif. Teknik analisis deskriptif yaitu untuk variabel yang bersifat kuantitatif. Penelitian ini menggunakan kuesioner sebagai alat untuk mengukur penelitian. Kegiatan analisis data dalam penelitian dilakukan melalui tahapantahapan sebagai berikut: Menyusun data ,Menyeleksi data untuk memeriksa kesempurnaan dan kebenaran data terkumpul, tabulasi data, pengujian.

Penelitian ini menggunakan analisis deskriptif untuk mendeskripsikan variabel dimensi kepuasan pelanggan.

\section{HASIL PENELITIAN DAN PEMBAHASAN}

Gambaran dimensi kepuasan pelanggan berikut rekapitulasi perolehan skor berdasarkan hasil pengolahan data variabel kepuasan pelanggan:

TABEL 3.1

REKAPITULASI DIMENSI KEPUASAN PELANGGAN

\begin{tabular}{ccccc}
\hline No. & Dimensi & $\begin{array}{l}\text { Total } \\
\text { Skor }\end{array}$ & $\begin{array}{c}\text { Skor } \\
\text { Ideal }\end{array}$ & $\%$ \\
\hline 1. & $\begin{array}{l}\text { Expectation } \\
\text { Satisfaction }\end{array}$ & 2845 & 4263 & $35,8 \%$
\end{tabular}

\begin{tabular}{|c|c|c|c|c|}
\hline 2. & $\begin{array}{l}\text { Overall } \\
\text { Satisfaction }\end{array}$ & 2002 & 2842 & $25,2 \%$ \\
\hline 3. & $\begin{array}{l}\text { Experience } \\
\text { Satisfaction. }\end{array}$ & 3094 & 4263 & $39 \%$ \\
\hline & Total & 7941 & 11368 & $100 \%$ \\
\hline
\end{tabular}

Sumber: Pengolahan Data 2017

Berdasarkan hasil penelitian dari angket yang disebar kepada 203 responden diketahui bahwa kepuasan pelanggan Perusahaan Jasa Ekspedisi Sicepat mencapai skor mencapai 7941 dari skor kriterium atau jumlah maksimal perolehan nilai responden terletak pada daerah puas yaitu pada interval 7192 - 8584 sehingga dapat dikatakan bahwa dalam penelitian ini kepuasan pelanggan yang dimiliki oleh pelanggan
Perusahaan Jasa Ekspedisi Sicepat sudah puas dan perusahaan telah berusaha untuk meningkatkan kepuasan pelanggannya, namun variabel kepuasan pelanggan perlu ditingkatkan lagi karena semua dimensiberada dibawah skor ideal. Skor tertinggi berdasarkan hasil jawaban responden terdapat pada dimensi experience satisfaction memperoleh skor sebanyak 3094 atau $39 \%$, Dalam hal ini pelanggan merasa senang menggunakan jasa pengiriman Sicepat. Skor terendah diperoleh pada dimensi Overall Satisfaction sebesar 25,2\% hal tersebut disebabkan pelanggan masih merasa belum seluruhnya puas terhadap pelayanan yang diberikan Sicepat. Perolehan Skor berdasarkan hasil pengolahan 7941 dari skor ideal 11368 atau bias dilihat pada garis kontinum berikut ini:

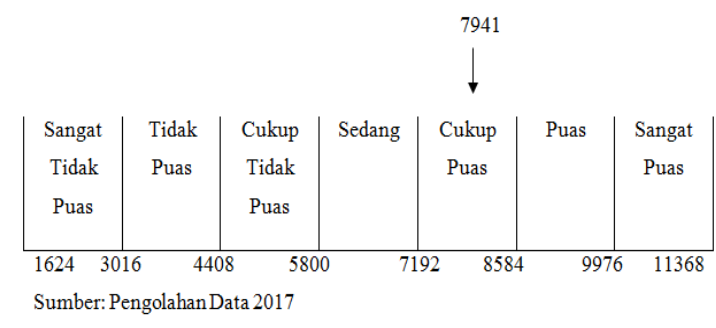

Melihat gambar diatas variabel kepuasan pelanggan berada pada kategori cukup puas. Namun secara keseluruhan pelanggan belum sepenuhnya merasa puas terhadap pelayanan yang diberikan. Pelanggan akan memberikan ulasan yang baik dan peringkat tinggi, jika apa yang ditawarkan oleh perusahaan sesuai dengan keinginan mereka.

\section{KESIMPULAN}

Hasil penelitian menyatakan bahwa kepuasan pelanggan pada komunitas online shop di Indonesia kedalam kategori cukup baik. Dimensi yang memiliki skor paling tinggi terdapat pada dimensi experience satisfaction sedangkan dimensi yang memiliki skor paling rendah terdapat pada dimensi overall satisfaction.

\section{REKOMENDASI}

Hasil penelitian menyatakan kepuasan pelanggan pada komunitas online shop di Indonesia, maka penulis merekomendasikan agar perusahaan sicepat dapat terus meningkatkan kinerja kepuasan pelanggan. Penelitian ini juga diharapkan dapat menjadi dasar untuk dilakukannya penelitian lain mengenai kepuasan pelanggantetapi dengan indikator serta objek yang berbeda. 


\section{DAFTAR PUSTAKA}

Aaker, David A. Kumar dan Day. 2004. Marketing Research $\left(\right.$ Ed $\left.8^{\text {th }}\right)$. John Willey dan Sons. United State of America.

Al-Rasyid, Harun. 1994. Teknik Penarikan Sampel dan penyusunan skala. Bandung: Universitas Padjadjaran

Delafrooz, Taleghani, Taghineghad dan Nademi. 2013. The impact of service innovation on consumer satisfaction. International Journal of Business and Behavioral Sciences. Vol.3, No.2.pp.114-129.

Fandy, Tjiptono. 2011. Pemasaran Jasa. Bayu Media:Malang.

Grewal dan Levy. 2014. Marketing. 40 ${ }^{\text {th }}$ Edition. United States of America.

Hurriyati, Ratih. 2010. Penerapan Model Strategi Pemasaran Usaha Kecil Berbasis Web 2.0 Sebagai Upaya Dalam Meningkatkan Daya Saing Industri Kecil.

Kotler dan Keller. 2016. Marketing Management. United State Pearson Education Limited.

Lili Adi Wibowo dan Yeni Yuniawati. (2007). The Influence of Tourist Product Attribute and Trust to Tourist Satisfaction and Loyalty A Study of Mini Vacation in Bandung Oleh: Journal of Chemical Information and Modeling, 53(9), 16891699.

Maymand, Mahmoudi. 2005. Global Strategic Management.

Naresh K, Maholtra. 2009. Basic Marketing Research. $3^{\text {th }}$ edition. New Jersey: Prentice Hall
Rahayu, A., \& Anggarini, G. (2009). Pengaruh Atribut produk wisata terhadap kepuasan wisatawan, 9-02

Rangkuti, Freddy. 2009. Strategi promosi yang kreatif.

Thurau,Thoursten and Alexander Klee. 1977. The Impact of Customer Satisfaction and Relationship Quality on Customer Retention: A Critical Reassessment and Model Development. Psychology and Marketing. Vol.14, No. 8, pp.737-764.

Sugiyono. (2013). Metode Penelitian Kuantitatif Kualitatif dan $R \& D$. Bandung: Alfabeta

Zeithaml,V.A.,Bitner, M.J. and Gremeler,D.D. 2009. Service marketing: integrating customer focus across the firm. Singapore: Mc Graw-Hill. 